\title{
Pengaruh Media Pembelajaran E-Modul Berbasis Sigil Terhadap Motivasi Belajar Siswa pada Mata Pelajaran Desain Grafis
}

\author{
Melgi Andari Putri, Ary Purmadi \\ Program Studi Teknologi Pendidikan, Fakultas Ilmu Pendidikan dan Psikologi \\ Universitas Pendidikan Mandalika Mataram \\ Corresponding Author. Email: melgiputri98@gmail.com
}

\begin{abstract}
The purpose of this study was to analyze the effect of sigil-based emodule learning media on student learning motivation in graphic design subjects in class X Multimedia at SMKN 1 Lingsar. The research method used was experimental. This study used a population of 36 students. The data collection methods used in this study were questionnaires, observation and documentation. The data analysis technique used statistical analysis with the chi square formula. The results of the analysis obtained the value $=12.462$ while the chi square value in the table with $\mathrm{db}=4$ with a significance level of $5 \%=$ 9.488 so that the value of the chi square analysis is greater than the value of the chi square table (12.462> 9.488). So it can be concluded that there is an effect of sigil-based e-module learning media on student learning motivation in graphic design subjects in class X Multimedia at SMKN 1 Lingsar.
\end{abstract}

\begin{abstract}
Abstrak: Tujuan dari penelitian ini adalah untuk menganalisis pengaruh media pembelajaran e-modul berbasis sigil terhadap motivasi belajar siswa pada mata pelajaran desain grafis kelas X Multimedia di SMKN 1 Lingsar. Metode penelitian yang digunakan adalah eksperimen. Penelitian ini menggunakan populasi sebanyak 36 siswa. Metode pengumpulan data yang digunakan dalam penelitian ini adalah angket, observasi dan dokumentasi. Teknik analisis data menggunakan analisis statistik dengan rumus chi square. Hasil analisis diperoleh nilai $=12,462$ sedangkan nilai chi square dalam tabel dengan $\mathrm{db}=4$ dengan taraf signifikansi $5 \%=9,488$ dengan demikian bahwa nilai chi square analisis lebih besar daripada nilai chi square tabel $(12,462>9,488)$. Sehingga dapat disimpulkan bahwa ada pengaruh media pembelajaran $e$-modul berbasis sigil terhadap motivasi belajar siswa pada mata pelajaran desain grafis kelas $\mathrm{X}$ Multimedia di SMKN 1 Lingsar.
\end{abstract}

Key Words:

Learning Media, Sigil, EModule, Motivation.

\section{Kata Kunci:}

Media Pembelajaran, E-

Modul, Sigil, Motivasi

Belajar.

How to Cite: Putri, M., \& Purmadi, A. (2020). Pengaruh Media Pembelajaran E-Modul Berbasis Sigil Terhadap Motivasi Belajar Siswa pada Mata Pelajaran Desain Grafis. Jurnal Teknologi Pendidikan, 5(2), 174-180. Retrieved from http://ojs.ikipmataram.ac.id/index.php/itp/article/view/3073

\section{Pendahuluan}

Laporan Program For International Student Assessment (PISA) pada tahun 2017 Indonesia menempati peringkat pendidikan urutan ke 57 dari total 65 negara dari segi membaca, matematika dan ilmu pengetahuan. Melihat peringkat tersebut masalah utama dalam pendidikan di sekolah dikarenakan masih kurangnya motivasi atau minat belajar siswa dalam mengikuti proses belajar mengajar di dalam kelas, hal ini dikarenakan siswa dipaksa menghafal dan membayangkan konsep sehingga siswa masih belum mampu mengaitkan pembelajaran dengan dunia nyata dan materi pembelajaran hanya sebatas imajinasi siswa, tak jarang hal tersebut dapat mempengaruhi motivasi atau minat siswa dalam mengikuti proses belajar.

Berdasarkan hasil observasi yang dilakukan di SMKN 1 Lingsar pada tanggal 26 Oktober 2019, ditemukan beberapa masalah yang dihadapi khususnya pada mata pelajaran 
desain grafis yaitu sebagian besar siswa tidak memiliki motivasi dalam mengikuti pembelajaran hal itu terlihat ketika saat proses pembelajaran berlangsung siswa kurang memperhatikan penjelasan guru, banyak siswa yang sibuk sendiri, keluar masuk kelas dan ketika guru memberikan pertanyaan banyak siswa yang tidak menjawab. kelas dan ketika guru memberikan pertanyaan banyak siswa yang tidak menjawab.

Dengan Demikian untuk membangkitkan motivasi belajar siswa pada mata pelajaran desain grafis hal perlu dilakukan oleh guru. yaitu dengan menggunakan media pembelajaran yang menarik sehingga dapat meningkatkan motivasi siswa dalam mengikuti proses pembelajaran seperti yang dikatakan oleh Faturrahman, dkk (2012) salah satu manfaat dari media pembelajaran ini yaitu akan lebih menarik perhatian siswa sehingga dapat menumbuhkan motivasi siswa untuk belajar.

Salah satu media yang dapat digunakan adalah media pembelajaran E-modul berbasis Sigil. Media pembelajaran E-modul berbasis Sigil merupakan media pembelajaran berbasis multimedia yang dapat menunjang pembelajaran di kelas. E-modul berbasis Sigil merupakan modul elektronik yang berisikan teks, gambar, audio, video yang dapat dibaca di komputer, laptop, tablet atau smartphone. Media ini menjadi salah satu alternatif media pembelajaran yang sangat berbeda dengan buku cetak, e-modul ini dapat memuat konten multimedia di dalamnya, sehingga dapat menyajikan bahan ajar yang lebih menarik dan membuat pembelajaran menjadi lebih menyenangkan (SEAMOLEC, 2014).

Menurut Purwaningtyas, dkk (2017) kelebihan dari e-modul yaitu : 1)Mudah dioperasikan. 2) Dilengkapi video, audio, teks dan gambar. 3) Dapat dibuka melalui komputer, smartphone,android dan tablet. 4) Pengguna dapat belajar kapan saja dan di mana saja. 5) Dalam pembelajaran dapat digunakan di dalam kelas maupun luar kelas. Menurut Amalia dan Kustijono (2017) kelebihan Software Sigil yaitu: 1) Dapat diperoleh secara gratis. 2) Aplikasi pembuat buku digital dengan fitur terlengkap dari pada software lain yang sejenis. 3) Running test dan hasil prototipe ringan dan mudah dioperasikan. 4) Friendly pada semua jenis perangkat pembaca dan fleksibel dalam pemakaian. Adapun tujuan penelitian ini adalah untuk menganalisis pengaruh media pembelajaran e-modul berbasis sigil terhadap motivasi belajar siswa kelas X Multimedia pada mata pelajaran desain grafis di SMKN 1 Lingsar.

\section{Metode Penelitian}

Metode penelitian yang digunakan dalam penelitian ini adalah metode eksperimen. Metode eksperimen merupakan metode penelitian yang memungkinkan peneliti memanipulasi data variabel dan meneliti akibat-akibatnya (Mahmud, 2011). Desain eksperimen yang digunakan adalah One-Group-Pretest-Posttest. Dalam ujicoba tidak menggunakan kelompok kontrol. Desain ini dilakukan dengan membandingkan hasil pretest dan posttest pada kelompok yang diuji cobakan.

$$
\mathrm{O}_{1} \mathrm{X} \mathrm{O}_{2}
$$

\section{Gambar 1. Rancangan Penelitian}

Keterangan

$\mathrm{O}_{1}=$ Nilai perencanaan penelitian (Sebelum diberikan perlakuan)

$\mathrm{O}_{2}=$ Nilai perencanaan penelitian (Setelah duberikan perlakuan)

$\mathrm{X}=$ Perlakuan

Sumber : Sugiyono (2015) 
Selanjutnya, "Populasi adalah wilayah generalisasi yang terdiri atas obyek atau subjek yang mempunyai kualitas dan karakteristik tertentu yang ditetapkan oleh peneliti untuk dipelajari dan kemudian ditarik kesimpulan" (Sugiyono, 2017). Sedangkan menurut Arikunto (2013) "populasi adalah keseluruhan subjek penelitian yang melibatkan semua elemen yang ada dalam wilayah penelitian". Berdasarkan kedua pendapat diatas, maka dapat dikatakan bahwa populasi dari penelitian ini adalah seluruh siswa kelas X Multimedia di SMKN 1 Lingsar Kabupaten Lombok Barat tahun ajaran 2019/2020 yang berjumlah 36 siswa. Menurut Sugiyono, (2017) "sampel adalah bagian dari jumlah dan karakteristik yang dimiliki oleh populasi tersebut". Sedangkan menurut Arikunto (2013) "sampel adalah sebagian atau wakil dari populasi yang diteliti". Dalam penelitian ini peneliti tidak menggunakan sampel tetapi populasi yaitu sebanyak 36 siswa.

Dalam sebuah penelitian dibutuhkan beberapa instrument yang dapat menunjang dan mendukung penelitian sehingga dapat berlangsung dengan baik. Instrument penelitian merupakan sebuah alat yang digunakan untuk mengumpulkan atau informasi yang bermanfaat untuk menjawab permasalahan penelitian. Instrumen yang digunakan oleh peneliti adalah angket sebagai metode pokok, observasi dan dokumentasi sebagai metode pendukung. Dalam hal ini angket dibuat oleh peneliti berdasarkan indikator motivasi belajar guna memperoleh data motivasi belajar siswa dengan menggunakan media pembelajaran $E$ modul berbasis Sigil. Angket ini terdiri dari lima alternatif pilihan jawaban yaitu : 1, 2, 3, 4 dan 5 dengan pemberian skor adalah sebagai berikut (1) sangat tidak setuju yaitu diberi skor 1, (2) tidak setuju yaitu diberi skor 2, (3) Kurang setuju yaitu diberi skor 3, (4) Setuju yaitu diberi skor 4 dan (5) sangat setuju yaitu diberi skor 5 .

Dalam suatu penelitian tentu akan melalui proses analisis data untuk mendapatkan hasil penelitian yang valid. Dalam memproses data memerlukan beberapa langkah terutama yang berkaitan dengan masalah subjek dan objek penelitian yang diperoleh dari hasil pengumpulan data melalui pengisian, setelah data terkumpul maka langkah selanjutnya adalah mengolah data atau menganalisis data tersebut secara statistik.

Sugiyono (2010) mengatakan bahwa "analisis data adalah mengelompokkan data berdasarkan variabel dan jenis responden, menyajikan data tiap-tiap variabel yang diteliti, melakukan perhitungan untuk menguji hipotesis yang telah ditunjukkan". Adapaun teknik analisis data yang digunakan dalam penelitian ini adalah analisis data statistik dengan rumus Chi-Square sebagai berikut :

$X^{2}=\sum\left[\frac{\left(f_{o}-f_{e}\right)^{2}}{f_{e}}\right]$

Keterangan :

$X^{2}=$ Nilai Chi-Kuadrat

$f_{o}=$ Frekuensi observasi (Frekuensi empiris)

$f_{e}=$ frekuensi yang diharapkan (Frekuensi teoritis)

(Riduwan, 2009)

\section{Hasil Penelitian dan Pembahasan}

Deskripsi data hasil penelitian ini dapat dijabarkan sebagai berikur.

Merumuskan Hipotesis Nihil $\left(\mathrm{H}_{o}\right)$

Untuk keperluan perhitungan analisis statistik, maka hipotesis nihil yang berbunyi "tidak ada Pengaruh Media Pembelajaran E-Modul Berbasis Sigil Terhadap Motivasi Belajar Siswa 
Pada Mata Pelajaran Desain Grafis Kelas X Multimedia di SMKN 1 Lingsar Kabupaten Lombok Barat Tahun Pelajaran 2019/2020”.

Membuat Tabel Kerja

Tabel 1. Data Rekapitulasi Skor Data Awal dan Data Akhir Siswa Laki-Laki

\begin{tabular}{|c|c|c|c|c|}
\hline No & Kode Subjek & $\mathbf{L} / \mathbf{P}$ & $\begin{array}{c}f_{o} \text { (Freuensi } \\
\text { Observasi) }\end{array}$ & $\begin{array}{c}f_{e} \text { (Frekuensi } \\
\text { Harapan) }\end{array}$ \\
\hline (1) & (2) & (3) & (4) & (5) \\
\hline 1 & AP & $\mathrm{L}$ & 51 & 98 \\
\hline 2 & $\mathrm{~A}$ & $\mathrm{~L}$ & 71 & 104 \\
\hline 3 & $\mathrm{AZ}$ & $\mathrm{L}$ & 79 & 110 \\
\hline 4 & $\mathrm{BH}$ & $\mathrm{L}$ & 80 & 95 \\
\hline 5 & $\mathrm{DH}$ & $\mathrm{L}$ & 79 & 101 \\
\hline 6 & DA & L & 75 & 105 \\
\hline 7 & HR & $\mathrm{L}$ & 86 & 90 \\
\hline 8 & IG & $\mathrm{L}$ & 73 & 104 \\
\hline 9 & IP & $\mathrm{L}$ & 82 & 90 \\
\hline 10 & IZ & $\mathrm{L}$ & 82 & 90 \\
\hline 11 & IFF & $\mathrm{L}$ & 82 & 95 \\
\hline 12 & KW & $\mathrm{L}$ & 84 & 86 \\
\hline 13 & MTA & $\mathrm{L}$ & 86 & 99 \\
\hline 14 & WK & $\mathrm{L}$ & 88 & 109 \\
\hline 15 & WJS & $\mathrm{L}$ & 63 & 90 \\
\hline \multicolumn{3}{|c|}{ Total } & 1161 & 1466 \\
\hline
\end{tabular}

Tabel 2. Data Rekapitulasi Skor Data Awal dan Data Akhir Siswa Perempuan

\begin{tabular}{|l|l|c|c|c|}
\hline No & Kode Subjek & L/P & $\begin{array}{l}\mathbf{f}_{\boldsymbol{o}} \text { (Freuensi } \\
\text { Observasi) }\end{array}$ & $\begin{array}{l}\mathbf{f}_{\boldsymbol{e}} \text { (Frekuensi } \\
\text { Harapan) }\end{array}$ \\
\hline $\mathbf{( 1 )}$ & $\mathbf{( 2 )}$ & $\mathbf{( 3 )}$ & $\mathbf{( 4 )}$ & $\mathbf{( 5 )}$ \\
\hline 1 & ARP & $\mathrm{P}$ & 80 & 91 \\
\hline 2 & EA & $\mathrm{P}$ & 83 & 94 \\
\hline 3 & FA & $\mathrm{P}$ & 90 & 96 \\
\hline 4 & F & $\mathrm{P}$ & 82 & 109 \\
\hline 5 & IDA & $\mathrm{P}$ & 84 & 88 \\
\hline 6 & ISA & $\mathrm{P}$ & 72 & 96 \\
\hline 7 & LEY & $\mathrm{P}$ & 88 & 98 \\
\hline 8 & MP & $\mathrm{P}$ & 70 & 97 \\
\hline 9 & MA & $\mathrm{P}$ & 76 & 90 \\
\hline 10 & NA & $\mathrm{P}$ & 82 & 101 \\
\hline 11 & NLA & $\mathrm{P}$ & 89 & 98 \\
\hline 12 & NLL & $\mathrm{P}$ & 70 & 91 \\
\hline 13 & NDA & $\mathrm{P}$ & 73 & 125 \\
\hline 14 & P & $\mathrm{P}$ & 77 & 88 \\
\hline 15 & RS & $\mathrm{P}$ & 74 & 100 \\
\hline 16 & STA & & $\mathbf{1 3 3 5}$ & $\mathbf{1 6 5 3}$ \\
\hline 17 & SI \\
\hline
\end{tabular}

Tabel 3. Tabel Kerja Pengujian Hipotesis Pengaruh Media Pembelajaran E-Modul Berbasis Sigil Terhadap Motivasi Belajar Siswa

\begin{tabular}{|c|c|c|c|c|c|}
\hline Subjek & $\mathbf{f}_{\mathbf{0}}$ & $\mathbf{f}_{\mathbf{e}}$ & $\mathbf{f}_{\mathbf{o}}-\mathbf{f}_{\mathbf{e}}$ & $\left(\mathbf{f}_{\mathbf{o}}-\mathbf{f}_{\mathbf{e}}\right)^{\mathbf{2}}$ & $\frac{\left(\mathbf{f}_{\mathbf{o}}-\mathbf{f}_{\mathbf{e}}\right)^{\mathbf{2}}}{\mathbf{f}_{\mathbf{e}}}$ \\
\hline $\mathbf{( 1 )}$ & $\mathbf{( 2 )}$ & $\mathbf{( 3 )}$ & $\mathbf{( 4 )}$ & $\mathbf{( 5 )}$ & $\mathbf{( 6 )}$ \\
\hline $\mathbf{L}$ & 1161 & 1466 & -305 & 93,795 & 6,345 \\
\hline $\mathbf{P}$ & 1335 & 1653 & -318 & 101,124 & 6,117 \\
\hline Jumlah & & & & & $\mathbf{1 2 , 4 6 2}$ \\
\hline
\end{tabular}




\section{Memasukkan Data Dalam Rumus}

Dari tabel di atas diketahui nilai yang didapatkan menggunakan rumus Chi Square adalah;

$$
\begin{gathered}
X^{2}=\sum\left[\frac{\left(f_{o}-f_{e}\right)^{2}}{f_{e}}\right] \\
X^{2}=12,462
\end{gathered}
$$

Sesuai dengan hasil perhitungan chi square yang diperoleh melalui analisis ternyata nilai yang diperoleh $=12,462$, sedangkan nilai chi square dalam tabel dengan $\mathrm{db}(\mathrm{C}-1) \times(\mathrm{R}-1)=$ $(5-1) \times(2-1)=4 \times 1=4$ dengan taraf signifikan $5 \%=9,488$ dengan demikian bahwa chi square analisis lebih besar daripada nilai chi square tabel $(12,462>9,488)$. Hal ini berarti hipotesis nihil ditolak dan hipotesis alternatif diterima.

Dari analisis data tentang penggunaan media pembelajaran E-Modul Berbasis Sigil dengan motivasi belajar siswa maka chi square analisis yang ditemukan sebesar 12,462. Dan persentase pengaruh media pembelajaran E-modul berbasis Sigil terhadap motivasi belajar siswa pada mata pelajaran desain grafis sebesar 77,9\%, jadi berdasarkan persentase tersebut dapat diketahui bahwa pengaruh media pembelajaran E-modul berbasis Sigil tergolong tinggi. Hasil yang kuat ini juga dikarenakan penggunaan media pembelajaran E-Modul Berbasis Sigil dapat mempengaruhi motivasi belajar siswa kelas X di SMKN 1 Lingsar dan juga dapat dilihat dari antusias siswa dalam pelaksanaan proses belajar mengajar di dalam kelas, hingga membuat proses belajar mengajar sesuai dengan yang diharapkan. Namun dalam penelitian ini peneliti memiliki keterbatasan yaitu responden yang hadir selama proses penelitian tidak sesuai dengan hasil observasi awal yaitu seharusnya responden sebanyak 36 orang, namun responden yang hadir selama proses penelitian sebanyak 32 orang.

Dari hasil chi square tabel menunjukkan bahwa $X_{\text {hitung }}^{2}$ sebesar 12,462 maka berdasarkan tarif signifikan 5\% ternyata besar angka penolakan hipotesis nihil yang dinyatakan dalam $X_{\text {tabel }}^{2}$ adalah 9,488 . Kenyatakaan ini menunjukkan bahwa $X_{\text {hitung }}^{2}$ lebih besar daripada $X_{\text {tabel }}^{2}$ dengan demikian hipotesis alternatif (Ha) yang berbunyi ada Pengaruh Media Pembelajaran E-Modul Berbasis Sigil Terhadap Motivasi Belajar Siswa Pada Mata Pelajaran Desain Grafis Kelas X Multimedia di SMKN 1 Lingsar Kabupaten Lombok Barat Tahun Pelajaran 2019/2020 di "Terima". Adapun hipotesis nihil (Ho) yang berbunyi tidak ada Pengaruh Media Pembelajaran E-Modul Berbasis Sigil Terhadap Motivasi Belajar Siswa Pada Mata Pelajaran Desain Grafis Kelas X Multimedia di SMKN 1 Lingsar Kabupaten Lombok Barat Tahun Pelajaran 2019/2020 di "Tolak". Penelitian ini juga didukung oleh hasil penelitian terdahulu yang dilakukan oleh Sari (2016: 46) bahwa penggunaan media pembelajaran yang tepat dan bervariasi dalam proses pembelajaran dapat meningkatkan motivasi belajar siswa, salah satu media yang dapat digunakan yaitu media pembelajaran $E$ Modul Berbasis Sigil. Karena melalui media pembelajaran yang dibuat dengan aplikasi Sigil ini dapat menjadikan pembelajaran lebih menarik, mudah dipahami dan praktis digunakan sehingga hal ini dapat meningkatkan motivasi siswa dalam mengikuti proses pembelajaran.

\section{Kesimpulan}

Berdasarkan hasil penelitian yang telah dilakukan dapat disimpulkan bahwa terdapat pengaruh media pembelajaran e-modul berbasis sigil terhadap motivasi belajar siswa pada mata pelajaran desain grafis kelas X Multimedia di SMKN 1 Lingsar. Hal ini dibuktikan dengan chi square hitung lebih besar daripada nilai chi square tabel $(12,462>9,488)$ dengan 
taraf signifikan 5\%. Kenyataan ini menunjukkan bahwa $X^{2}$ hitung lebih besar daripada $X^{2}{ }_{t a b e l}$ dengan demikian hipotesis alternatif (Ha) yang berbunyi ada Pengaruh Media Pembelajaran E-Modul Berbasis Sigil Terhadap Motivasi Belajar Siswa Pada Mata Pelajaran Desain Grafis Kelas X Multimedia di SMKN 1 Lingsar.

\section{Daftar Pustaka}

Amalia., F., Z., dan Kustijono, R. (2017). Efektivitas Penggunaan E-book Fisika Menggunakan Sigil Untuk Melatih Keterampilan Berpikir Kritis ; 84 (http://fisika.fmipa.unesa.ac.id/index.php/snf/article/view/42 Diakses 04 Novemver 2019 Pukul 07.29 WITA)

Arikunto., S. (2013). Prosedur Penelitian Suatu Pendekatan Peraktik. Jakarta: Rineka Cipta

Fadli, M., \& Ikawati, H. (2017). PENGGUNAAN MULTIMEDIA UNTUK MENINGKATKAN MOTIVASI BELAJAR SISWA. Jurnal Teknologi Pendidikan, 2(2), 35-43.

Retrieved

from http://ojs.ikipmataram.ac.id/index.php/jtp/article/view/598

Faturrahman,. Dkk. (2012). Pengantar Pendidikan. Jakarta: Prestasi Pustaka Publisher

Handayani, L. (2020). Peningkatan Motivasi Belajar IPA Melalui Model Pembelajaran Project Based Learning pada Masa Pandemi Covid-19 bagi Siswa SMP Negeri 4 Gunungsari. Jurnal Paedagogy, 7(3), 168-174. doi:https://doi.org/10.33394/jp.v7i3.2726

Lasiati, L. (2016). Meningkatkan Motivasi Belajar Peserta Didik dengan Menerapkan Model Reading Guide Berbasis PAIKEM. Jurnal Kependidikan: Jurnal Hasil Penelitian dan Kajian Kepustakaan di Bidang Pendidikan, Pengajaran dan Pembelajaran, 2(1). doi:https://doi.org/10.33394/jk.v2i1.431

Mahmud. (2011). Metode Penelitian Pendidikan. Bandung: Pustaka Setia

Purwaningtyas, dkk. (2017). Pengembangan Modul Elektronik Mata Pelajaran Pendidikan Jasmasi, Olahraga, dan Kesehatan Kelas XI Berbasis Online Dengan Program Edmodo. 127 (http://jurnal.um.ac.id/index.php/jptpp/article/view/8471 Diakses 03 November 2019 Pukul 20.10 WITA)

Putri, N., \& Muzakkir, M. (2019). PENGARUH MEDIA TUTORIAL BERBENTUK FILM (MOTION PICTURES) TERHADAP MOTIVASI BELAJAR SISWA. Jurnal Teknologi Pendidikan, O(2), 60-70. from http://ojs.ikipmataram.ac.id/index.php/itp/article/view/1240

Riduwan. (2009). Belajar Mudah Penelitian Untuk Guru-Kariyawan dan Peneliti Pemula. Bandung: Alfabeta

Sari., S., A. (2016). Pengembangan Buku Digital Melalui Aplikasi Sigil Pada Mata Kuliah Cookies and Candys. 46 (http://jurnal.ustjogja.ac.id/index.php/sciencetech/article/view/1266 Diakses 03 Novemver 2019 Pukul 20.27 WITA )

Setiarini, A. (2016). Meningkatkan Motivasi dan Hasil Belajar Peserta Didik dengan Mengoptimalkan Penerapan Pendekatan Saintifik Strategi Discovery Learning dan Metode Diskusi di SDN Model Mataram. Jurnal Kependidikan: Jurnal Hasil Penelitian dan Kajian Kepustakaan di Bidang Pendidikan, Pengajaran dan Pembelajaran, 2(1). doi:https://doi.org/10.33394/jk.v2i1.390

Southheast Asian Ministers of Education Organization Regional Open Learning Center (SEAMOLEC). (2014). Sumber Buku : Buku Digital. Pelatihan Buku Digital 26 Maret 2014 
Sugiyono. (2010). Metode Penelitian dan Pendidikan. Bandung: Alfabeta . (2015). Metode Penelitian dan Pengembangan. Bandung: Alfabeta . (2017). Metode Penelitian dan Pendidikan (Pendekatan Kuantitatif, Kualitatif dan $R \& D)$. Bandung: Alfabeta

Wibawa, R., \& Lukitasari, D. (2020). PENGARUH PENGGUNAAN MODEL PEMBELAJARAN OTENTIK TERHADAP MOTIVASI BELAJAR. Jurnal Teknologi Pendidikan, 4(1), 53-61. Retrieved from http://ojs.ikipmataram.ac.id/index.php/jtp/article/view/2257 